\title{
ENGLISH FOR SECRETARIAL PROGRAM: TARGET AND LEARNING NEEDS OF 'CINTA KASIH TZU CHI' VOCATIONAL SCHOOL STUDENTS
}

\author{
Junita and Nurdiana* \\ English Language and Culture Department, Bunda Mulia University \\ Received on 1 April 2019 / Approved on 10 April 2019
}

\begin{abstract}
English is one of compulsory subjects in vocational high schools. It is a required school subject as students of vocational school graduates are prepared to work based on their major and skills. In addition, in the workplace context, English is the common foreign language used in and among divisions in the workplace. To help the students use the language appropriately, schools need to prepare them with adequate learning materials. Thus, reliable sources of learning, one of which is English coursebooks, should incorporate appropriate language input for the students specifically devised for vocational school students. Unfortunately, most of the coursebooks contain materials which do not meet target and learning needs of the students who study in vocational schools. Therefore, this study aimed at examining their target and learning needs of English, particularly for those taking secretarial program. In order to achieve the objective of the study, a questionnaire consisting of target and learning needs items was distributed to the subjects of the research. The findings of this research revealed that the target needs of the students who majored in the secretarial program are to be able to communicate in English both in oral and written texts, vocabulary enhancement related to the workplace, and to pass the national exam. As for the learning needs, most of the students are keen on learning English from authentic materials integrated in all language skills.
\end{abstract}

Keywords: materials development, target and learning needs, ESP

\begin{abstract}
ABSTRAK
Bahasa Inggris adalah salah satu mata pelajaran wajib di Sekolah Menengah Kejuruan. Ini adalah mata pelajaran wajib sekolah karena siswa lulusan sekolah kejuruan dipersiapkan untuk siap bekerja sesuai dengan jurusan dan keterampilan mereka. Bahasa Inggris adalah bahasa asing yang umumnya digunakan di tempat kerja. Untuk membantu siswa menggunakan bahasa dengan tepat, sekolah perlu menyiapkan materi pembelajaran yang memadai dan sesuai untuk mereka. Dengan demikian, sumber belajar yang dapat diandalkan, salah satunya buku pelajaran bahasa Inggris, sejatinya mengandung 'input' bahasa yang sesuai untuk siswa yang dirancang khusus untuk siswa sekolah kejuruan. Namun, sebagian besar buku pelajaran berisi materi yang tidak memenuhi kebutuhan siswa yang belajar di sekolah kejuruan. Oleh karena itu, penelitian ini bertujuan untuk memeriksa target mereka dan kebutuhan belajar bahasa Inggris, terutama bagi mereka yang mengambil program kesekretariatan. Untuk mencapai tujuan penelitian, kuesioner target dan kebutuhan belajar didistribusikan kepada subjek penelitian. Temuan dari penelitian ini adalah bahwa siswa ingin mengerti bahasa Inggris baik dalam teks lisan maupun tulisan, peningkatan kosakata terkait dengan tempat kerja, dan lulus ujian nasional. Adapun kebutuhan belajar, sebagian besar siswa menginginkan bahan pelajaran yang terintegrasi dengan menggunakan bahan-bahan otentik.
\end{abstract}

Kata Kunci: pengembangan materi, target dan kebutuhan pembelajaran, ESP

*Author(s) Correspondence:

E-mail: junitahartono95@gmail.com,nurdiana@bundamulia.ac.id 


\section{INTRODUCTION}

Vocational High Schools prepare students to master the skills of their expertise and to be prepared to work. Many job vacancies put English as one of the requirements since English is commonly used in a workplace. Students will have greater chance of getting a job if they master English. In order to do so, teaching and learning materials for vocational school students should cater English for specific purposes.

After observing English syllabus for vocational school students and the materials, it turned out that many of them are too general for all majors in Vocational High School. Students would have a better result if they learn English accordance with their major and expertise. Unfortunately, the textbooks needed are still rare. They are not specifically designed for any major in the schools. The use of inappropriate materials will make language learning objectives hard to achieve. In addition, appropriate and suitable materials can make the students learn English more easily. It is because they are learning the materials that are related to their expertise and suitable for their needs.

For this reason, the present paper aims to investigate the target and learning needs of English for students studying at 'Cinta Kasih Tzu Chi' Vocational High School majoring in secretarial program. This school has two study programs: Accounting and Secretary. In fact, the school only provides one English textbook and one syllabus for these two majors. After a carefully examination on the textbook and the syllabus, it turned out that the materials used in the school are less specific and are not related to their study program.

\section{LITERATURE REVIEW}

\subsection{Needs Analysis}

Hutchinson and Waters (1987) state that ESP is an approach which is based on the learners' needs. In other words, ESP helps teachers to teach students based on their needs and more specific to their expertise. Moreover, it helps the students master English easily since they learn English based on what they need. Thus, to find what students' need, needs analysis should be conducted before teaching and learning process. Hutchinson and Waters (1987) further define needs as the ability to learn and to produce the language aspects into two categories: target needs and learning needs. The target needs are what knowledge and abilities the learner needs to do in the target situation. They are necessities, lacks, and wants.

1. Necessities

To find out what the learners needs based on the target situation.

2. Lacks

To find out the gap between what the learners have known and what they should achieve.

3. Wants

To find out what the reasons of the learners learn the language and what the goal they want to achieve after learning the language.

Hutchinson and Waters (1987) propose a framework for analyzing learning needs. The checklist is presented below:

1. Why are the learners taking the course?

- Compulsory or optional;

- Apparent need or not;

- Are status, money, promotion involved?

- What do learners think they will achieve?

- What is their attitude toward the ESP course? Do they want to improve their English or they resent the time they have spent on it?

2. How do the learners learn?

- What is their learning background?

- What is their concept of teaching and learning?

- What methodology will appeal to them?

*Author(s) Correspondence:

E-mail: junitahartono95@gmail.com,nurdiana@bundamulia.ac.id 
- What sort of techniques are likely to borel alienate them? What resources are available?

- Number and professional competence of teachers;

- $\quad$ Attitude of teachers to ESP;

- Teacher's knowledge of and attitude to the subject content;

- Materials;

- Aids;

- Opportunities for out-of-class activities

3. Who are the learners?

- Ages/ sex/ nationality;

- What do they know already about English?

- What subject knowledge do they have?

- What are their socio-cultural background?

- What teaching styles are they used to?

- What is their attitude to English or to the culture of the English speaking world?

4. Where will the ESP course take place?

- Are the surrounding pleasant, dull, noisy, cold, etc?

- $\quad$ Time of day;

- Everyday/ once a week;

- $\quad$ Full-timel part-time;

- Concurrent with need or preneed

\subsection{Content-Based Instruction}

Content-based instruction is used in the process of materials development since it will be accordance to the contents of the materials. Richards and Rodgers (2001) acknowledge that CBI is an approach to second language teaching which focuses on the content and information that will be acquired by students. In addition, Richards and Rodgers (2001) state the principles of CBI deal with the real communication, the exchange of information, and experiential content which become the focus in language teaching.
This is also likewise related to the objectives of national education in the secondary school.

There are some concepts of CBI principles proposed by some experts. According to Brinton (as cited in Nunan, 2004), principles of CBI are divided into five items:

1. The principle is base instructional decisions on content rather than language criteria. In CBI, content is the important aspect because from the content material developers can consider the language items.

2. The principle is integrating skills. Developing materials which use CBI approach always include integrated skills (listening, speaking, reading and writing) while putting grammar and vocabulary as parts of it.

3. The principle is involving students actively in all phases of the learning process. CBI believes that learners can learn better if they include in the learning process because they will not always depend on the teacher as the source of information.

4. The principle is choosing content for its relevance to student's lives, interest and/or academic goals. The students' need is important to be found here since the choice of the content in CBI course depends on it. In SMK or vocational school context, the content can be organized based on the study programs.

5. The last principle is selecting authentic texts and tasks. Authenticity is a key component in CBI which brings the learners real-life content.

On the whole that content has important value to be focused on, for students can acquired easily. The other that should be considered is authentic material indeed which relates in real life.

\section{RESEARCH METHOD}

To examine the target and the learning needs of English for the secretarial program,

\footnotetext{
*Author(s) Correspondence:

E-mail: junitahartono95@gmail.com,nurdiana@bundamulia.ac.id
} 
the present study employed needs analysis questionnaire made based on the theory of needs assessment designed by Hutchinson and Waters (1987), Graves (2000), and Nunan (2004) which covered the present learning, and target situation of the students. The questionnaire was distributed to $3210^{\text {th }}$ graders of 'Cinta Kasih Tzu Chi' Vocational High School majoring in secretarial program.

\section{FINDINGS AND DISCUSSION}

\subsection{Target Needs}

According to Hutchinson and Waters (1987), target needs include necessities, lacks, and wants of the students. In terms of students' view about their target situation, the data shows that $84.3 \%$ students claimed that their main goal of studying English is to be able to communicate in English both written and spoken while $9.4 \%$ students expected to enhance their vocabulary related to their future jobs. $6.3 \%$ students intended to pass the national exam. The topics of language learning they were interested in were any material regarding business administration, for example, handling telephone, making letters, and handling a meeting. The students' English proficiency level is still in the beginner where they are only able to comprehend simple sentences and utterances in the daily life. On the other hand, to be relevant with their future jobs, their English skills should be at least in the intermediate level. They are required to be able to comprehend and to use every word, sentence, and utterance in English correlated to their future jobs by integrating materials in the four basic skills of English.

\subsection{Learning Needs}

According to Nunan (2004), spoken, written and visual data that students use to complete any task is called input which might be taken from various sources. Most students are more interested in learning English from authentic materials such as, those from You Tube, magazines, news, films, and songs. This is due to authentic materials contain real life situations which might help the students understand the materials easily.

As the students expected the incorporation of the four basic skills in language learning materials, the findings revealed that for listening and reading skills, they preferred to have medium length of listening and reading input. Implicitly, they needed an average audio and reading texts related to listening and reading tasks. In addition, the students favored reading tasks which contain lists of new vocabulary. For speaking and writing skills, they preferred tasks which were relevant to their future jobs.

Input is not the only aspect of learning needs. Nunan (2004) said that procedure, which is another element of learning needs, explains more about what the learners will actually do with the input in order to achieve every goal of the tasks. For listening skills, the students favored common language expressions used in particular situations, for example, language expressions on handling telephones, business correspondence, and handling a meeting. They considered these expressions important because they were applicable in workplace context.

The results of the questionnaire indicated that the students preferred to have various classroom activities for each skill. For speaking skills, their preferences were demonstrating dialogs or monologs, writing a dialog and demonstrating it, role-play, discussing a topic and giving opinion about the topic, presenting a report, story-telling, public speaking, etc. Meanwhile, the students need to learn note-taking skills for specific details, retelling a story with own words, identifying the general point of the text, identifying the detail information of the text by answering the questions provided, and completing blanks on an incomplete text for listening skills. As for reading skills, reading a text and answering some questions about the text, discussing the topic of the text, reading aloud, arranging jumbled paragraph into a well meaningful paragraph, and summarizing a text were the students' preferences. Regarding writing skills, arranging jumbled paragraph into a wellmeaning paragraph, rewriting a text as same as

\footnotetext{
*Author(s) Correspondence:

E-mail: junitahartono95@gmail.com,nurdiana@bundamulia.ac.id
} 
the model text, writing a text based on pictures, tables, diagrams, or graphics provided, completing blanks on an incomplete paragraph, and writing simple text became favorable classroom activities.

Nunan (2004) further said that tasks impinge on classroom arrangements. The results of the questionnaire showed that ten students (out of thirty-two students) preferred to do a task in the classroom while the other ten students wanted to do a task outside the classroom. Consequently, teaching and learning process would be in various places which depend on the situation and time. Doing a task in a small group was one of the students' favorite classroom activities whereas the teachers said that how the tasks conducted was based on the topic of the materials. In addition, teacher's and students' role can be different since it will depend on the tasks and topic themselves.

\section{CONCLUSION}

To sum up, there are three target needs of English for secretarial program for 'Cinta Kasih Tzu Chi' Vocational High School students. Regarding the students' necessities, the relevant topics are handling telephone, business correspondence, and handling a meeting. Meanwhile, related to the students' lacks, their current level was in the beginner whereas they should reach intermediate level in order to be corresponding to their future jobs.

As for their learning needs, this study revealed that their main goal of studying
English is to be able to communicate in English in both written and spoken texts, to enhance their vocabulary related to their future jobs, and to pass the national exam. The topics of language learning they were interested in were any material regarding business administration covering the four basic skills of English, (reading, listening, writing, and speaking). The students are interested in learning English using authentic materials which correspondent with their work life situation in the future. They also expected numerous activities in the classroom that cover the basic skills of English.

\section{REFERENCES}

Graves, K. (2000). Designing language courses: a guide for teachers. Canada: Heinle \& Heinle Publishers.

Hutchinson, T, \& Waters, A. (1987). English for specific purpose. Cambridge: Cambridge University Press.

Nunan, D. (2004). Task-based language teaching. Cambridge: Cambridge University Press.

Richards, J.C., \& Rodgers, T.S. (2001). Approaches and methods in language Teaching $\quad\left(2^{\text {nd }} \quad\right.$ ed. $) . \quad$ Cambridge: Cambridge University Press.

*Author(s) Correspondence:

E-mail: junitahartono95@gmail.com,nurdiana@bundamulia.ac.id 